\title{
Pregnancy Induced Hypertension: A Study on Its Multisystem Involvement
}

IJCRR

Section: Healthcare

Sci. Journal

Impact Factor 4.016

ICV: 71.54

\section{Karanpreet Bhutani ${ }^{1}$, Chittranjan Vij², Manjeet Kaur ${ }^{3}$, Gurdeep Kaur Bedi ${ }^{4}$}

'Senior Resident, Department of Biochemistry, Government Medical College, Patiala, India; ${ }^{2}$ Professor, Department of Biochemistry, Mmu,

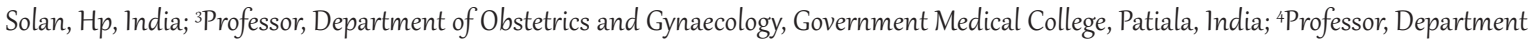
of Biochemistry, Government Medical College, Patiala.

\section{ABSTRACT}

Objectives: To evaluate and compare Renal, Hepatic and Coagulation profiles in normotensive pregnant females at 20 weeks or more gestation and in cases of Pregnancy induced Hypertension at same gestation.

Methods: The study was conducted on 100 pregnant females divided into two groups of 50 each: cases of PIH (Study group) and normotensive pregnant females (Control group) and all these females were at 20 weeks or more gestation. Blood sample was collected at the period of gestation when they attended Gynaecology OPD at Rajindra Hospital, Patiala. Blood Urea, S. Creatinine, S. Uric Acid, S. Transaminases and Platelet count were evaluated and compared.

Results: The mean Blood Urea was $25.92 \pm 6.16 \mathrm{mg} \%$ (study group) compared to $24.60 \pm 3.21 \mathrm{mg} \%$ (control group) ( $p=0.1823$ ). The difference did not attain statistical significance. The mean S. creatinine was $1.05 \pm 0.19 \mathrm{mg} \%$ (study group) compared to $0.71 \pm 0.20$ $\mathrm{mg} \%$ (control group) ( $\mathrm{p}<0.0001$ ) while the mean S. uric acid was $5.43 \pm 1.25 \mathrm{mg} \%$ (study group) compared to $3.86 \pm 0.72 \mathrm{mg} \%$ (control group) $(\mathrm{p}<0.0001)$ and the difference was statistically highly significant. The mean AST levels were $57.42 \pm 58.26 \mathrm{IU} / \mathrm{L}(\mathrm{study}$ group) compared to $25.02 \pm 6.32 \mathrm{IU} / \mathrm{L}$ (control group) $(p=0.0002$ ) while the mean ALT levels were $51.80 \pm 53.98 \mathrm{IU} / \mathrm{L}$ (study group) compared to $24.04 \pm 8.56 \mathrm{IU} / \mathrm{L}$ (control group)( $\mathrm{p}=0.0005)$. The mean platelet count was $223700.00 \pm 70239.02 \mathrm{~mm}^{3}$ (study group) compared to $314860.00 \pm 33815.83 \mathrm{~mm}^{3}$ (control group) $(p<0.0001)$. The difference was statistically highly significant.

Conclusion: Patients with PIH have altered renal, hepatic and coagulation profiles thereby deranging the function of different organs. Timely assessment of various blood parameters in such patients will help in preventing occurrence of $\mathrm{PIH}$ and in planning proper intervention to improve both maternal and fetal outcome in established pre-eclamptic women.

Key Words: Pregnancy induced hypertension, Renal, Hepatic, Coagulation Profiles

\section{INTRODUCTION}

Pregnancy is a physiological process. To supply adequate nutrition to the growing fetus, maternal physiological adjustments of different organ systems occur in pregnancy. The adjustments are circulatory, metabolic and hormonal. ${ }^{[1]}$ The term 'Pregnancy induced hypertension' (PIH) is defined as the hypertension that develops as a direct result of the gravid state. ${ }^{[2]}$ Pre-Eclampsia is a multisystem disorder of unknown etiology characterized by development of hypertension to the extent of 140/90 mm Hg or more with proteinuria after the $20^{\text {th }}$ week in a previously normotensive and non-proteinuric patient with or without pathological oedema. ${ }^{[2]}$

In addition to the elevated blood pressure and proteinuria, women with pre-eclampsia often have signs or symptoms indicating dysfunction of any of several organ systems, including the renal, gastrointestinal, coagulation and central nervous system. Cardiac complications are rare but heart failure may occur generally in women with preexisting heart disease. ${ }^{[3]}$

Involvement of the renal system is characteristic of pre-eclampsia and the presence of proteinuria is part of the definition of this disorder. With increasing severity of disease, creatinine clearance declines; acute tubular necrosis and frank renal failure may occur. ${ }^{[3]}$

Pathologic changes in the liver in woman with pre-eclampsia reflect ischemic damage. Transaminases elevation indicate hepatocellular necrosis. ${ }^{[3]}$

\section{Corresponding Author:}

Dr. Karanpreet Bhutan, Senior Resident, Department of Biochemistry, Government Medical College, Patiala; E-mail: karanpreet.biochem@gmail.com

ISSN: 2231-2196 (Print)

Received: 03.07.2017
ISSN: 0975-5241 (Online)

Revised: 19.08.2017
Accepted: 02.02 .2018 


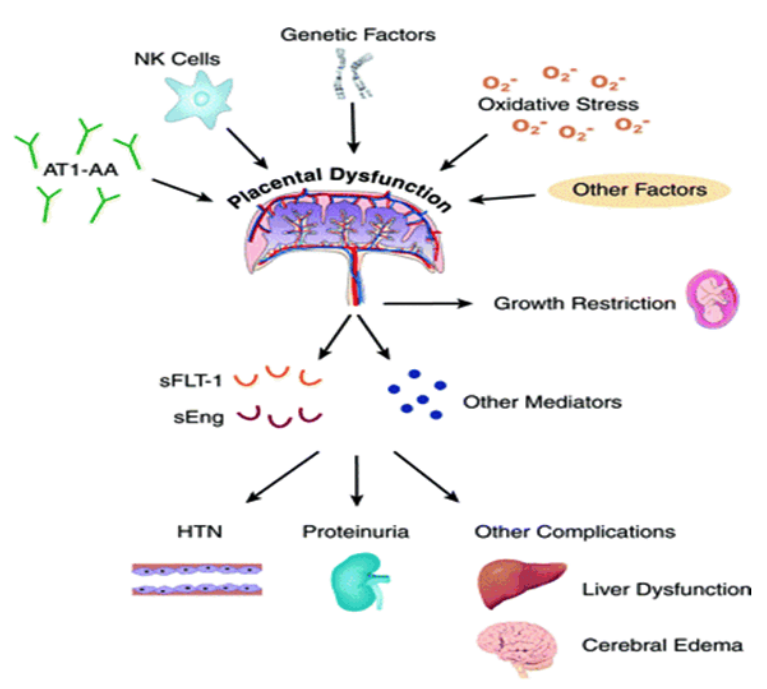

Figure Summary of the pathogenesis of preeclampsia. Angiotensin II Type I Receptor Activating Autoantibodies (AT1-AA), immunologic factors, oxidative stress, and other factors (such as decreased heme oxygenase expression) may cause placental dysfunction, which in turn leads to the release of antiangiogenic factors (such as sFlt1 and soluble endoglin [sEng]) and other inflammatory mediators to induce preeclampsia. NK indicates natural killer; HTN, hypertension.

Hematological manifestations which include Low platelet counts may complicate pre-eclampsia. Microangiopathic hemolytic anaemia may be present and is believed to be secondary to endothelial damage. ${ }^{[3]}$

Pregnancy induced hypertension continues to be a major obstetric problem in present day healthcare practice. It presents a great medical dilemma because it affects not only maternal health but also puts foetal development at risk [4].

So in the background of altered renal, hepatic and hematological manifestations being potential risk factors for occurrence of PIH, the present study aims to evaluate and compare blood urea, S. creatinine, S.uric acid, Serum Transaminases (AST/ALT) and Platelet count in patients with PIH and normal pregnancy so that monitoring of blood parameters gives an indication on the severity and progress of the disease.

\section{MATERIALS AND METHODS}

The present study was conducted in the Department of Biochemistry, Government Medical College, Patiala on 100 pregnant females who were at 20 weeks or more gestation and were referred by the Department of Obstetrics and Gynaecology, Rajindra Hospital, Patiala. The study protocol was approved by the ethical committee of GMC, Patiala. Informed consent was taken from individual subjects.

\section{Study group}

It comprised of 50 pregnant females at 20 weeks or more gestation with Pregnancy induced hypertension. The criteria to diagnose pre-eclampsia was Blood pressure $\geq 140 / 90 \mathrm{mmHg}$ after 20 weeks' gestation and Proteinuria $\geq 300 \mathrm{mg} / 24$ hours or $\geq 1+$ dipstick as per National High Blood Pressure Education Program Working Group.

\section{Control group}

It comprised of 50 normotensive pregnant females at same gestation with no proteinuria and without any other systemic disease.

\section{Exclusion Criteria:}

All cases of previous history of essential hypertension or chronic hypertension, known cases of renal, hepatic or any other systemic disorders.

\section{Specimen collection:}

$5 \mathrm{ml}$ Blood sample was collected from these patients by venipuncture when they attended OPD at Rajindra Hospital, Patiala.

The serum was then separated by centrifugation of the sample at room temperature and supernatant was taken in a separate test tube. This serum was then used for analysis of blood urea, S. creatinine, S.uric acid, serum transaminases which include Aspartate transaminase (AST) and Alanine transaminase (ALT) and platelet count in the laboratory.

\section{Methodology:}

Blood urea was done using Berthelot's method [5], S. creatinine by Method of Brod and Sirota [6], S. Uric acid was done by colorimetric method of Caraway [7], AST/ALT using IFCC Kinetic method [8] and Platelet count using Newbauer counting chamber [9].

\section{Statistical analysis:}

It was done by student's t-test using SPSS version 10.0

\section{RESULTS}

Table 1 shows demographic characteristics of both the study and control groups. The mean age and period of gestation were comparable $\mathrm{n}$ both the groups. The mean SBP and DBP were significantly higher in the study group compared to the control group.

The mean Blood Urea in the study group was $25.92 \pm 6.16$ $\mathrm{mg} \%$ compared to $24.60 \pm 3.21 \mathrm{mg} \%$ in the control group $(\mathrm{p}=0.1823)$. The difference did not attain statistical significance. The mean S. creatinine in the study group was 
$1.05 \pm 0.19 \mathrm{mg} \%$ compared to $0.71 \pm 0.20 \mathrm{mg} \%$ in the control group ( $<<0.0001)$ and the difference was statistically highly significant. The mean $\mathrm{S}$. uric acid in the study group was $5.43 \pm 1.25 \mathrm{mg} \%$ compared to $3.86 \pm 0.72 \mathrm{mg} \%$ in the control group $(\mathrm{p}<0.0001)$ and the difference was statistically highly significant (Table 2) (Figure 1).

The mean AST levels in the study group were $57.42 \pm 58.26$ IU/L compared to $25.02 \pm 6.32 \mathrm{IU} / \mathrm{L}$ in the control group $(\mathrm{p}=0.0002)$ while the mean ALT levels in the study group were $51.80 \pm 53.98 \mathrm{IU} / \mathrm{L}$ compared to $24.04 \pm 8.56 \mathrm{IU} / \mathrm{L}$ in the control group ( $\mathrm{p}=0.0005)$. The difference in AST/ALT was highly significant in both the groups. (Table 3) (Figure 2).

The mean platelet count in the study group was $223700.00 \pm$ $70239.02 \mathrm{~mm}^{3}$ compared to $314860.00 \pm 33815.83 \mathrm{~mm}^{3}$ in the control group $(\mathrm{p}<0.0001)$. The difference was statistically highly significant. (Table 4) (Figure 3)

\section{DISCUSSION}

In the present study, the mean blood urea levels were comparable in both the groups. This finding matches with the study by Vibha et ${ }^{1}{ }^{[10]}$ while it is in contrast to the study by Vural et al[11](2000) according to which there was significant difference between 2 groups in terms of blood urea levels. The reason for difference may be that the study group comprised only of severe cases of PIH with blood pressure $\geq 160 / 110$ $\mathrm{mmHg}$ in the study conducted by Vural et al (2000) [11] while the present study included both non-severe and severe cases of PIH. The mean S. Creatinine levels in the patients of PIH were higher compared to normal pregnant females and this finding is comparable to studies by other researchers. The rise in serum creatinine levels in PIH is due to reduced renal perfusion and glomerular filteration. ${ }^{[2]}$ The mean S. uric acid levels in the present study is comparable to most of the studies. The rise in S.uric acid levels in PIH is attributed to reduced renal excretion of urate which is probably mediated by the systemic vasoconstriction, reduction in renal blood flow and decrease in glomerular filtration rate that accompany this disease. ${ }^{[13]}$

The mean platelet count in the study group was significantly lower compared to control group. Thrombocytopenia may be due to disseminated intravascular coagulation or an immune mechanism. ${ }^{[14]}$

Serum transaminases showed a significant difference in both the groups. Mechanism of raised liver enzymes is hypervascularisation and vasoconstriction of liver leading to cell injury, alteration of membrane permeability and damage to the hepatocytes. ${ }^{[15]}$

\section{CONCLUSION}

Instead of being simply 'one disease', PIH appears to be a culmination of factors that likely involve a number of maternal, placental and fetal factors. Patients with PIH have altered renal, hepatic and coagulation profiles thereby deranging the function of different organs. Timely assessment of various blood parameters in such patients will help in preventing occurrence of PIH and in planning proper intervention to improve both maternal and fetal outcome in established preeclamptic women.

\section{ACKNOWLEDGEMENT}

Authors acknowledge the immense help received from the scholars whose articles are cited and included in references of this manuscript. The authors are also grateful to authors/ editors/publishers of all those articles, journals and books from where the literature for this article has been reviewed and discussed.

\section{REFERENCES}

1. Kumar, A., Ghosh, B.K. and Murthy, N.S. Maternal thyroidal status in preeclampsia. Indian J. Med. Sci., 2005; 59: 57-63. Dutta DC, Konar H (editors). Textbook of Obstetrics including perinatology and contraception. $6^{\text {th }}$ Edition New Central Book Agency (P) Ltd. Calcutta. 2004; 221-222.

2. Dutta DC, Konar H (editors). Textbook of Obstetrics including perinatology and contraception. $6^{\text {th }}$ Edition New Central Book Agency (P) Ltd. Calcutta. 2004; 221-222.

3. Solomon CG and Seely EW. Hypertension in pregnancy. Endocrinol Metab Clin North Am 2006;35(1):157-71,vii.

4. Bellany L, Casas JP, Hingorani AD, Williams DJ. Preeclampsia and risk of cardio-vascular diseased cancer in later life: systematic review and meta-analysis. Br Med J 2007;335:974.

5. Henry RJ. Clinical Chemistry. Principles and Techniques. New York : Harper and Row Inc. New York 1964;4:268.

6. Brod J and Sirota JH. Renal clearance of endogenous creatinine in man. J Clin Invest 1948;27:645

7. Varley H. Non-Protein Nitrogen. In: Practical Clinical Biochemistry. 1980;5(1):451-487.

8. Moss DW and Henderson AR. Tietz Textbook of Clinical Chemistry. Burtis CA, Ashwood ER, eds. Philadelphia. Saunders and Company 1999;3:652.

9. Jain KA. Determination of Platelet count. In: Manual of Practical Physiology. Avichal Publishing Company 2000;60-61.

10. Vibha C, Krishna CSM, Mahadevappa KL. Lipids and Lipoprotein (a) $[\mathrm{Lp}(\mathrm{a})]$ in pregnancy Induced Hypertension. International Journal of Basic Medical Science 2011;2(2):73-77.

11. Vural P, Akgul C, Canbaz M. Calcium and Phosphate Excretion in Preeclampsia. Turk J Med Sci 2009;30:39-42.

12. Cunningham FG, Leveno KJ, Bloom SL, Hauth JC, Rouse DJ, Spong CY. Pregnancy Hypertension. In: Williams Obstetrics. McGraw-Hill 2010b;23(34): 706-56.

13. Sibai BM. Hypertension. In: Gabbe SG, Niebyl JR, Simpson JL, eds. Obstetrics - Normal and Problem Pregnancies. Philadelphia, Pa: Elsevier Churchill Livingstone 2007;5:33. 
14. Burrows RF, Hunter DJS, Andrew M, Kelton JG. A prospective study investigating the mechanism of thrombocytopenia in preeclampsia. Obstet Gynecol 1987;70:334-338.
15. Tubbergen P, Lachmeijer AM, Althuisius SM, Vlak ME, Van Geijn HP et al. Change in paternity : a risk factor for preeclampsia in multiparous women? J Reprod Immunol 1999;45:81-88.

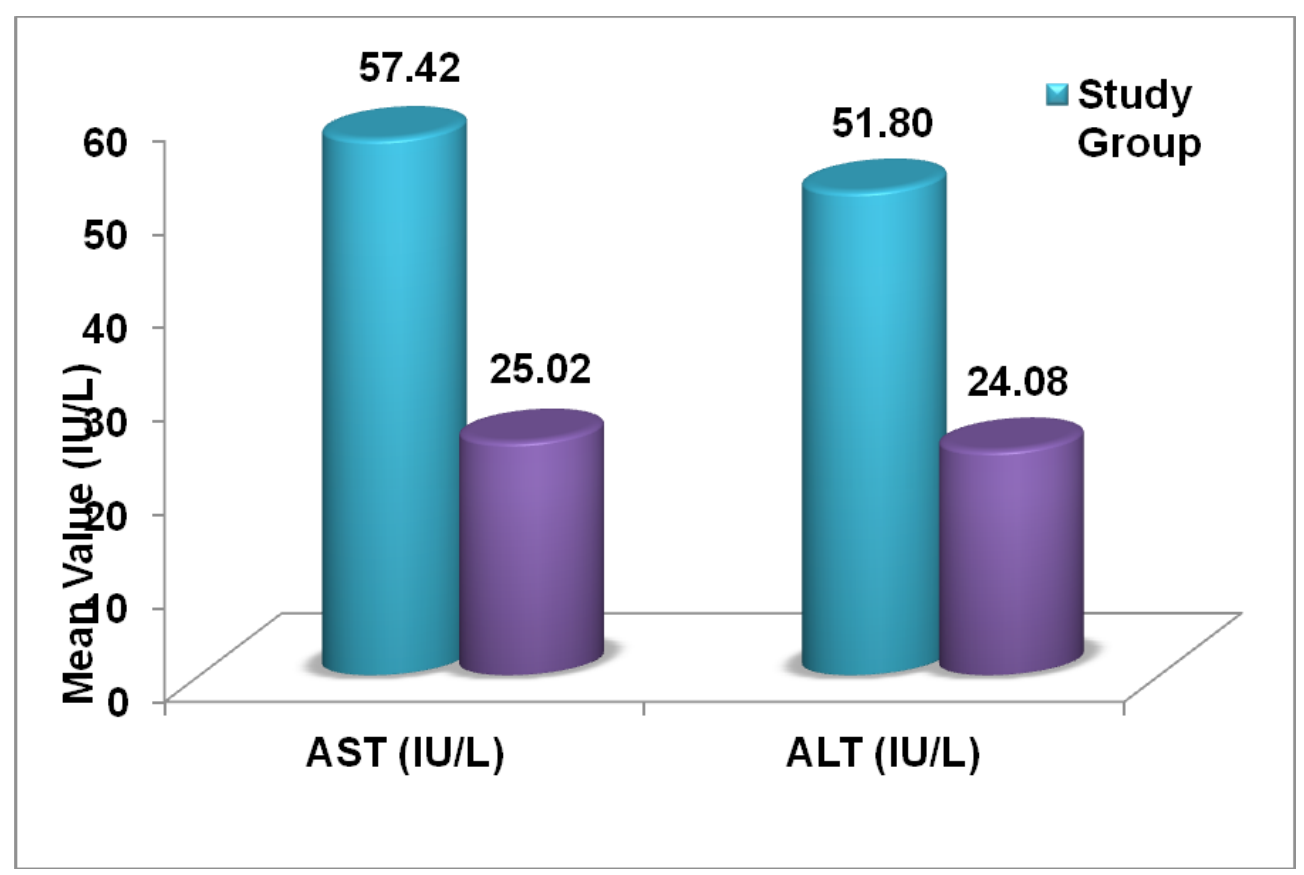

Figure 1: Comparison of Mean Blood Urea, Mean Serum Creatinine and Mean Serum Uric Acid in the Study and Control Groups.

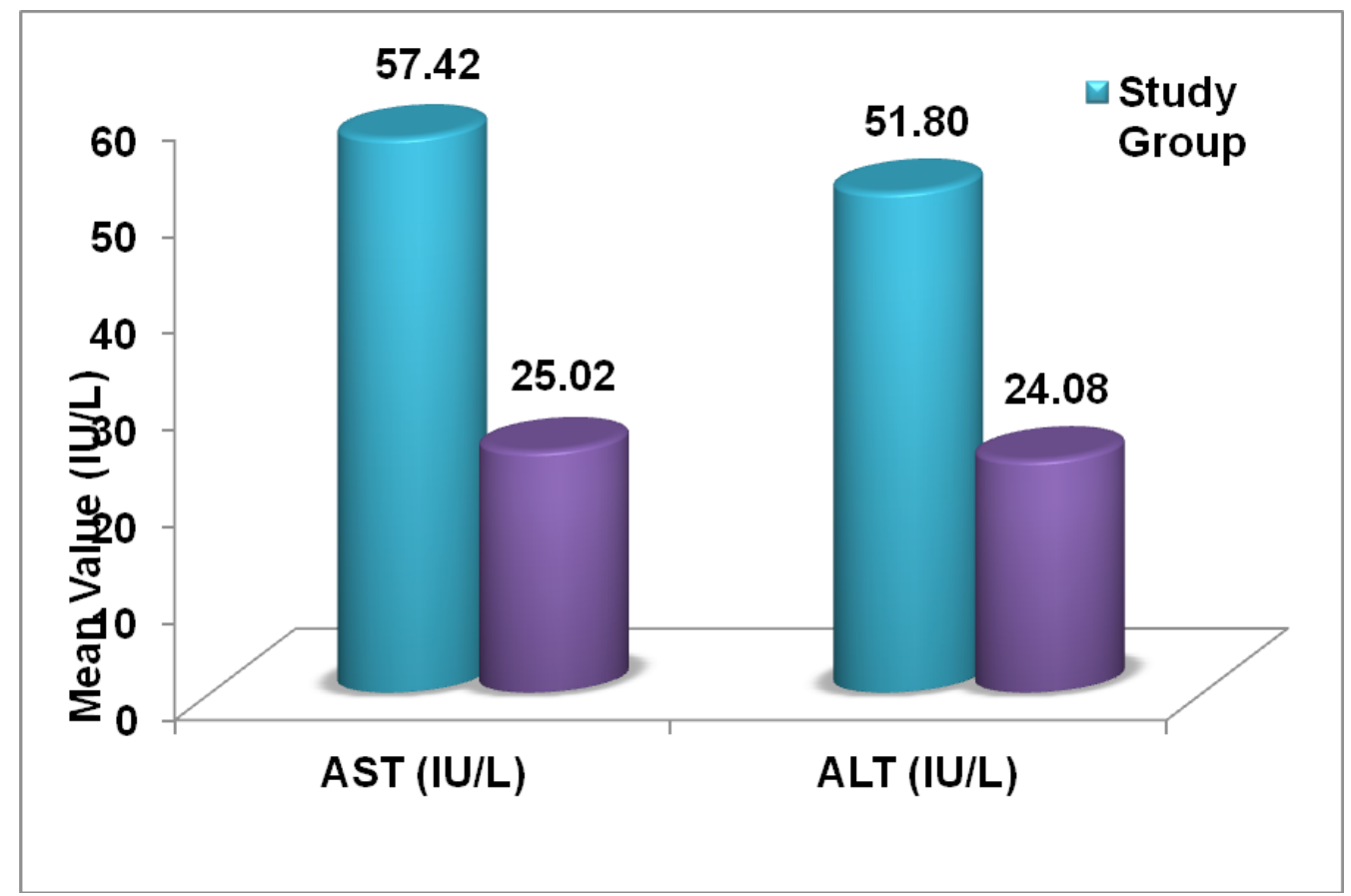

Figure 2: Comparison of Serum Aspartate Transaminase and Serum Alanine Transaminase Levels in the Study and Control Group. 


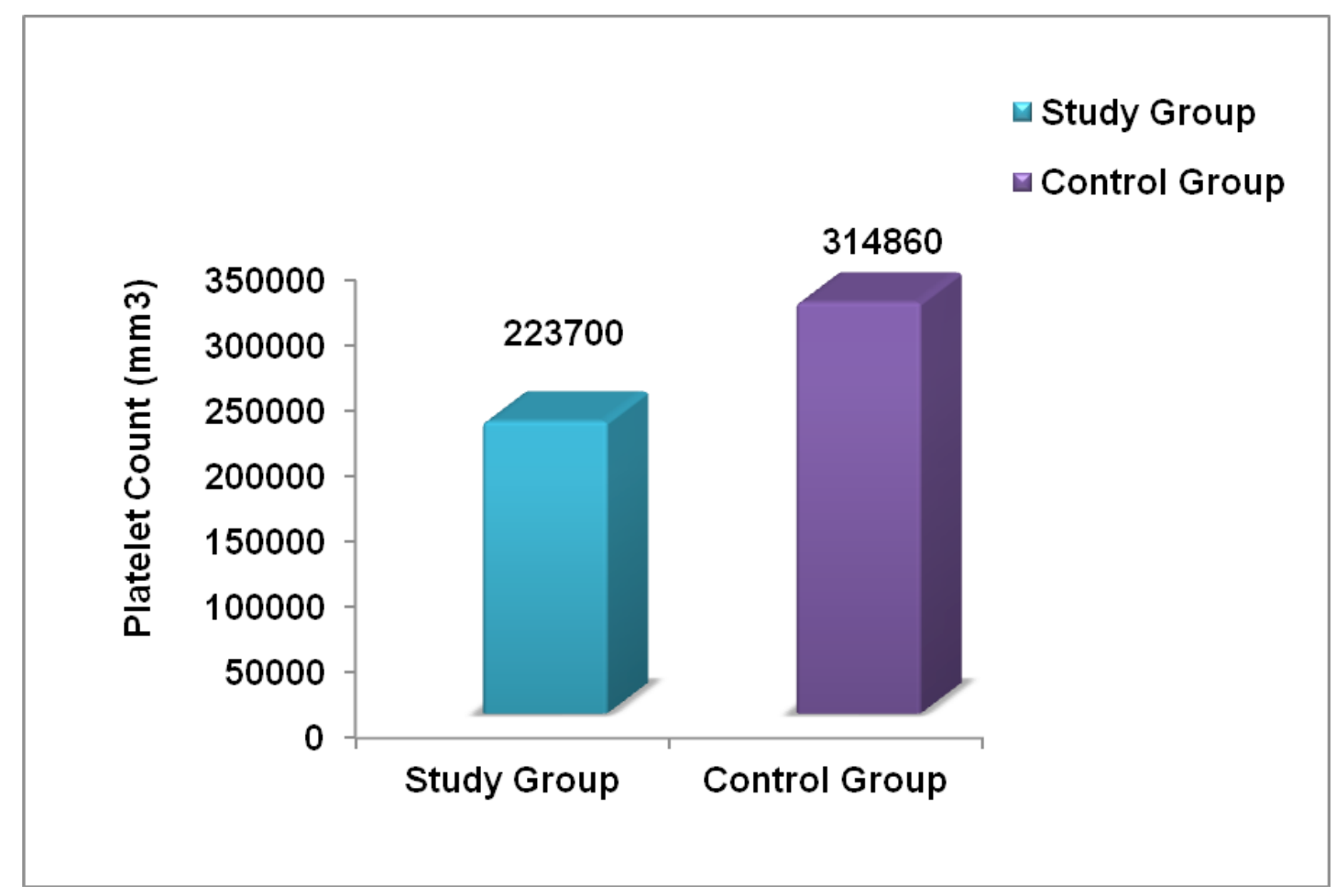

Figure 3: Comparison of Platelet Count in Study and Control Group.

Table 1: Demographic characteristics of study group and control group

\begin{tabular}{lcc} 
Parameter & Study group & Control group \\
Mean Age ( in years) & $25.12 \pm 3.95$ & $24.14 \pm 3.80$ \\
Mean Period of gestation( in weeks) & $32 \pm 3.68$ & $31 \pm 3.70$ \\
Body Mass Index $\left(\mathrm{kg} / \mathrm{m}^{2}\right)$ & 295.7 & $27 \pm 3.9$ \\
Mean S.B.P $(\mathrm{mmHg})$ & 155.6814 .68 & $115.68 \pm 7.08$ \\
Mean D.B.P $(\mathrm{mmHg})$ & 105.4811 .02 & $73.96 \pm 6.25$ \\
\hline
\end{tabular}

Table 2: Comparison of Mean Blood Urea, Mean Serum Creatinine and Mean Serum Uric Acid in the Study and Control Groups

\begin{tabular}{lllccc} 
& $\begin{array}{l}\text { Study Group } \\
(\text { Mean } \pm \text { SD })\end{array}$ & $\begin{array}{l}\text { Control Group } \\
(\text { Mean } \pm \text { SD })\end{array}$ & t & p & s \\
Blood Urea $(\mathrm{mg} \%)$ & $25.92 \pm 6.16$ & $24.60 \pm 3.21$ & 1.3434 & 0.1823 & NS \\
Serum Creatinine $(\mathrm{mg} \%)$ & $1.05 \pm 0.19$ & $0.71 \pm 0.20$ & 8.5353 & $<0.0001$ & Highly Significant \\
Serum Uric Acid $(\mathrm{mg} \%)$ & $5.43 \pm 1.25$ & $3.86 \pm 0.72$ & 7.6302 & $<0.0001$ & Highly Significant \\
\hline
\end{tabular}


Table 3: Comparison of Serum Aspartate Transaminase (AST) and Serum Alanine Transaminase (ALT) Levels in the Study and Control Groups

\begin{tabular}{lccccc} 
& $\begin{array}{c}\text { Study Group } \\
(\text { Mean } \pm \text { SD) }\end{array}$ & $\begin{array}{c}\text { Control Group } \\
(\text { Mean } \pm \text { SD) }\end{array}$ & t & P & s \\
AST (IU/L) & $57.42 \pm 58.26$ & $25.02 \pm 6.32$ & 3.9089 & 0.0002 & $\begin{array}{c}\text { Very } \\
\text { Significant } \\
\text { ALT (IU/L) }\end{array}$ \\
& $51.80 \pm 53.98$ & $24.08 \pm 8.56$ & 3.5857 & 0.0005 & $\begin{array}{c}\text { Very } \\
\text { Significant }\end{array}$ \\
\hline
\end{tabular}

Table 4: Comparison of Platelet Count in Study and Control Groups

\begin{tabular}{lccccc} 
& $\begin{array}{c}\text { Study Group } \\
(\text { Mean } \pm \text { SD })\end{array}$ & $\begin{array}{c}\text { Control Group } \\
(\text { Mean } \pm \text { SD })\end{array}$ & t & P & S \\
\hline $\begin{array}{l}\text { Platelet Count } \\
\left(\mathrm{mm}^{3}\right)\end{array}$ & 223700.00 & 314860.00 & 8.2688 & $<0.0001$ & Sighly \\
& \pm & \pm & & & Significant \\
\hline
\end{tabular}

